\title{
PR: More than a Goodwill
}

\author{
Heng Wang \\ School of International Economics and Trade \\ Shandong University of Finance \\ No. 40 Shungeng Road, Jinan 250014, China \\ E-mail:whhelen@hotmail.com
}

\begin{abstract}
One highly effective type of advertising costs virtually nothing: public relations. With public relations, the newsworthiness of some aspect of your business or business activities can earn you free publicity in newspapers or magazines, or even on radio or television. This paper provides an overview of what research teaches us about public relations and opens a dialog among practitioners and academics.
\end{abstract}

Keywords: Public Relations, Goodwill, Organization

\section{Introduction}

Public relation is about creating favourable images of the company or organisation in the mind of consumers. It often involves creating a news story or event that brings the product or company to the public attention. A news story is more likely to be read than an advertisement, and is also more likely to be believed.

PR differs from advertising in that the message is not paid for directly; the newspaper or magazine prints the story as news, and of course is able to slant the story any way it wishes to. PR people are usually ex-journalists who have kept some of their old contact, and who know how to create a story that will be printed in the way the company wants it to be done. Newspaper editors are wary of thinly disguised advertisements and will only print items that are really newsworthy.

\section{What is public relation}

Public relations is defined as "the planned and sustained effort to establish and maintain goodwill and mutual understanding between an organisation and its publics: customers, employees, shareholders, trade bodies, suppliers, Government officials, and society in general" (Institute of Public relations, 1984). The PR managers have the task of co-ordinating all the activities that make up the public face of the organisation, and will have some or all of the following activities to handle:

- Organizing press conferences;

- Staff training workshops;

- Events such as annual dinners;

- Handling incoming criticisms or complaints;

- Grooming senior management for the press or for TV appearances;

- Internal marketing, setting the organisation's culture towards a customer orientation.

The basic routes by which PR operates are word of mouth, press and TV news stories, and personal recommendation. The aim is to put the firm and its products into people's minds and conversations in a positive way. Because the information appears as news, it tends to carry more weight. PR is not advertising, because it is not paid for directly (even though there is usually some cost attached in terms of paying somebody to write the press release and also in creating a news story). Advertising can be both informative and persuasive, but PR is used for conveying information only.

Here are some examples of good PR activities:

- A press release saving that a company has developed a way of recycling garbage from landfills to produce plastics.

- The company sponsors a major charitable or sporting event (e.g. the London Marathon or a famine-relief project).

- An announcement that one of the firm's senior executives has been seconded to a major government job-creation programme. 
- The Body Shop requires all its franchise operations to run projects to benefit their local communities. This gives a positive image of the company to the community, and also gives the staff pride in working for a caring firm.

- McDonald's counters the negative publicity from environmental pressure groups by running litter patrols outside its restaurants.

These examples have in common that they are newsworthy and interesting, that they put the companies concerned in a good light, and that they encourage people to talk about the companies in a positive way.

Good PR can be much more effective than advertising, for the following reasons:

- The press coverage is free, so there is better use of the promotional budget.

- The message carries greater credibility because it is in the editorial part of the paper.

- The message is more likely to be read, because while readers tend to skip past the advertisements, their purpose in buying the paper is to read the news stories.

Like people, organisations have needs; a structure for these (based on Maslow's hierarchy) was developed by Pearson (1980). PR is helpful in meeting all the organisation's needs, but particularly those nearer the top of the hierarchy. Table 1 shows Pearson's hierarchy of organisational needs, with the lowest, most basic needs at the beginning of the table, and higher needs at the end.

Like Maslow's hierarchy, Pearson's hierarchy is useful as a concept but less useful as a practical guide, because so many firms deviate from the order in which the needs are met. For example, when Sony Corporation was founded by Akio Morita (and others) just after the Second World War, the directors decided that corporate unity and staff involvement would begin almost from day one, at a time when (due to post-war shortages) the company was having difficulty getting materials to work with and a factory to operate from. Morita arranged for the employees to have a company uniform so that the distinction between management and staff would be less obvious, and also to give the outside world a good impression of the firm (Morita, 1980). Incidentally, this also had a practical aspect - many of the employees had only ragged clothes or the remnants of their army uniforms, so Morita was able to ensure loyalty because so many of his staff literally had nothing else to wear except the company uniform.

Public relations activities cover a whole range of issues and should not be considered solely as a publicity device. PR has a strategic role to play in maintaining the organisation's reputation; Figure 1 shows the relationship between publicity, PR and press relations. PR occupies the overall strategic role, with publicity (creating news) and press relations (ensuring that news is printed) occupying the tactical positions.

PR has a key role to play in relationship marketing since it is concerned with building a long-term favourable image rather than gaining a quick sale. Relationship marketing is often compared to courtship and marriage: public relations is concerned with making a good impression before the first 'date' and with maintaining a good relationship during the 'courtship' and 'marriage'. To extend the analogy, PR ensures that the company is wearing its best clothes and is on its best behaviour, and remembers anniversaries and birthdays.

\section{Public relations and staff}

PR is largely about sending information and creating the right image for organisations and products, but it is also concerned with creating favourable impressions in people's minds. It is rarely, if ever, connected with directly bringing in business, and in this respect it differs from the other tools in the promotional mix. Although most of the time and for most activities PR will be the responsibility of a press agent or PR officer, PR is the responsibility of everybody who comes into contact with people outside the organisation. This will include the 'front-liners', the people whose day-to-day work brings them into contact with outsiders. For example:

- receptionists;

- telephonists;

- truck drivers;

- warehouse staff;

- serving staff in the canteen.

This is apart from the marketing staff, such as salespeople, who come into contact with outsiders as part of the overt marketing effort. In a sense, everybody in the organisation must take some responsibility for PR, since everybody in the organisation goes home after work (and discusses their company with their friends and families).

In this context, a bad approach to PR (but one that is all too common) is to hire somebody with a nice smile and a friendly voice to sit by the telephone to handle complaints and smooth over any problems that arise. This is a fire-fighting or reactive approach. 
A better approach to PR is to encourage all the staff to feel positive about the company. This is done by ensuring that everybody knows that in simple language what the organisation is doing, what the policies are and what the company's overall aims are. Most people would like to think they are working or a good, responsible successful organisation; it is part of the job of public relations to ensure that this is communicated to staff. This is sometimes done by using a slogan or company motto to sum up its main aim. Table 2 contains some examples.

Internal PR uses staff newsletters, training programmes and social events to convey a positive image. Because most of the front-liners are working away from the company's diktat, it would be impossible for PR staff to be everywhere at once, following people around to ensure that they say and do the 'right' things.

\section{Public relations and the press}

Usually, external PR communicates through the news media. Newspapers and magazines earn their money mainly through paid advertising, but they attract readers by carrying stimulating articles about topics of interest to the readership. Typically, a PR manager or agent will be an ex-journalist who understands what is newsworthy and what is not, and will be able to issue press releases about the company that are actually published. Table 3 shows the criteria according to which press releases must be produced if they are to stand a chance of being published.

There has been a substantial growth in the use of press releases and publicity in recent years. This is due to increasing consumer scepticism about advertisements. Press stories carry much greater credibility and, although they do not usually generate business directly, they do have a positive long-term effect in building brand awareness and loyalty.

The news media will, of course, reserve the right to alter stories, add to them, comment on them or otherwise change them around to suit their own purposes. For example, a press agent's great little story on the launch of Britain's most powerful sports car may become part of an article on dangerous driving. There is really very little the firm can do about this.

For this reason, a large part of the PR manager's job lies in cultivating good relationships with the media. Sometimes this will involve business entertaining, but more often it will involve making the journalists' lives as easy as possible. A well-written press release will often be inserted in the paper exactly as it stands, because the editorial staffs are too busy to waste time rewriting something that is already perfectly acceptable.

The journals and newspapers gain as well. Normally editors have to pay for editorial, either paying freelance writers to produce articles or paying the salaries of journalists to come up with interesting stories. A good press release can be published with little or no editing and no 'legwork' on the part of journalists, so it fills space with minimal cost to the paper.

Often companies will lay on a media event, a launch ceremony for a new product or to announce some change in company policy. Usually this will involve inviting journalists from the appropriate media, providing lunch with plenty of free drinks, and inviting questions about the new development in a formal press conference. This kind of event will only have a limited success, however, unless the groundwork for it has been very thoroughly laid.

Journalists tend to be suspicious of media events, sometimes feeling that the organisers are trying to buy them off with a buffet and a glass of wine. This means they may not respond positively to the message that the PR people are trying to convey, and may write a critical article rather than the positive one that was hoped for.

To minimize the chances of this happening, media events should follow these basic rules:

- Avoid calling a media event or press conference unless you are announcing something that the press will find interesting.

- Check that there are no negative connotations to what you are announcing.

- Ensure that you have some of the company's senior executives there to talk to the press, not just the PR people.

- Only invite journalists with whom you feel you have a good working relationship.

- Avoid being too lavish with the refreshments.

- Ensure that your senior executives, in fact anybody who is going to speak to the press, has had some training in doing this. This is particularly important for television.

- Be prepared to answer all questions truthfully. Journalists are trained to spot lies and evasions.

Journalists much prefer to be able to talk directly to genuine corporate executives rather than only being allowed to talk to the PR department; however, care should be exercised in ensuring that the executives spoken to be able to handle this type from journalists promptly, honestly and enthusiastically and can arrange interviews with senior personnel if necessary. 


\section{PR and other publics}

PR involves dealing with the company's other publics, apart from consumers. These are typically the following groups:

- Shareholders, for whom the company will produce end-of-year reports, special privileges and so forth;

- Government departments, with whom the company will liaise about planned legislation or other activities;

- The workforce;

- External pressure groups such as environmentalists or lobbyists.

Pressure groups can cause problems for companies by producing adverse publicity, by picketing company plants or by encouraging boycotting of company products. This can usually be dealt with most effectively by counter-publicity.

Sometimes adverse publicity from pressure groups is dealt with by advertising. For example, McDonald's was attacked by environmental groups for indirectly encouraging the destruction of rainforests for the purpose of producing cheap beef. McDonald's responded with a series of full-page press adverts asserting that beef for its hamburgers comes only from sources in the countries where it is eaten, and is not imported from developing countries.

A journalist who is offered a story by a pressure group will usually respond by trying to get the other side of the story from the firm. This is partly for legal reasons, since newspapers can be sued for libel if they print stories that turn out to be untrue, but it is also because most journalists are professionals and want to ensure the accuracy and fairness of their stories. This means that $\mathrm{f}$ firm's press office, a PR manager or even a senior executive may be asked for comment with little or no prior warning. It is therefore advisable to be as prepared as possible beforehand, and to answer as fully as possible any questions that you are asked. However, it is better to delay comment than to say something that will make matters worse!

In these circumstances, it is better to use a phrase such as 'I'm sorry, I'll have to look into that and get back to you later' than the standard 'No comment'. The former phrase at least gives the impression that you are trying to help, whereas 'No comment' gives the impression that you are trying to hide something.

Defensive PR is about responding to attacks from outside the firm and counteracting them as they arise. The attacks might come from pressure groups, from investigative reporters or from Members of Parliament. The safest way to handle this type of attack is to begin by trying to understand the enemy, and to this end the following questions should be asked:

- Are they justified in their criticism?

- What facts do they have at their disposal?

- Who are they trying to influence?

- How are they trying to do it?

If the pressure groups are justified in its criticisms, it may be necessary to bring about changes in the organisation in order to quell the criticism; otherwise the problem will simply continue. Good PR people will always respond in some way; as anyone who watches investigative reporters on television will know, the company managers and directors who flee with a hasty 'No comment' always look guilty, whereas the ones who are prepared to be interviewed always appear honest (until the reporter produces the irrefutable evidence, of course).

Proactive PR means setting out deliberately to influence opinion, without waiting for an attack from outside. Here the manager will decide on the following:

- Who do we need to influence?

- What do we need to influence them about?

- How can we influence them?

- How can we marshal the arguments carefully to maximise their impact?

Overall, it is probably better to be proactive rather than defensive (or reactive) because then the PR office is in control of the process and is better prepared. If the firm is planning on dumping toxic waste at a beauty spot, it is better to contact Greenpeace beforehand and get their opinion rather than suffer the inevitable protests afterwards and take a chance on being able to patch up any problems!

\section{What PR will do?}

The following is a list of what good PR will do for the firm:

- It helps build a positive image.

- It can counter bad publicity. 
- It can improve employee motivation.

- It can greatly improve the effectiveness of both the advertising and the sales force.

- On the other hand, here are some of the things that PR will NOT do for the firm;

- It will not directly increase sales.

- It will not cover up something that is adverse for the company.

- It will not replace other promotional activities.

Ultimately, PR works best as part of a planned and integrated programme of promotional activities that includes advertising, sales promotion and personal selling. It works least well when used only occasionally and in isolation.

\section{Internal PR}

The purpose of internal PR activities is to encourage employees to take a greater interest in their own work and in the organisation's goals. This has spin-offs for the staff themselves: most people would prefer to work for an organisation with a good record and most actually like to feel involved in their work. After all, work forms the dominant part of an employee's day; it is a large part of one's life and gives one the opportunity to do something useful.

Creating pride in the organisation and in work can be done by carrying out the tasks shown in Table 4. These factors were identified during a research study involving 82 companies over a five-year period (Kanter, 1985).

From the employee's perspective, the firm needs to supply answers to these questions (D'Aprix, 1987):

- What's my job?

- How am I doing?

- Does anybody give a damn?

Once the organization has answered these questions, the employee will want answers to others:

- How are we doing?

- How do we fit in to the whole?

- How can I help?

The final question is, of course, the one that the management of the firm is most ready to answer. The task of answering all these questions is part of the firm's internal PR systems. The tools used for this are sometimes generated by the public relations people, more often by the personnel departments of the firms concerned. Typical internal Pr tools are as follows:

- Internal newsletters.

- Staff magazines.

- Staff meetings.

For example, UK chocolate manufacturer Rowntree-Mackintosh established a comprehensive employee communications system during the mid-1970s and early finding solutions for problems at a local level. The company newspaper publishes five local editions every month; the employees get an annual company report of their own, in addition to twice-yearly briefings on the state of the business; there is a profit-sharing scheme in place as well as quality circles to maintain standards. Senior management report that involvement, trust and a greater level of understanding among employees has resulted in lower absenteeism and greater productivity. Also, it is difficult to find Rowntree-Mackintosh employees who complain about the firm they work for - an unusual situation (Arnott, 1987).

Most importantly, the person responsible for internal public relations must take the job further than merely maintaining the company notice board and writing a newsletter. There must be real commitment from management to the concept of good employee communications and relationships.

\section{International public relations}

As with any other form of marketing communications, PR is subject to cultural differences that alter the nature of the activities. In some cases, firms are able to transfer their PR activities without alteration, in some cases local modifications are carried out to an overall policy (as with Body Shop's community work initiatives, which are chosen by the staff in each shop); and in other case the PR activity is, by its nature, multinational (as with Formula One racing).

There are two main ways of handling business internationally: either through a company-owned local branch, which can deal with PR on the instructions of head office in the home country; or through agents and distributors, who are rather harder to control. Part of the problem with the latter arrangement is that the local distributors has its own reputation to uphold and will usually bend its PR efforts in enhancing its own standing. This means that local representation will be 
chosen on the basis of what will enhance the distributor's reputation rather than that of the parent company.

The media through which PR operates exist in all countries to a greater or lesser extent (although TV is not always available everywhere in developing countries). What is less obvious is that the media may occupy different levels of importance in different countries. For example, in much of Africa radio is far more important as a medium than newspapers, partly due to higher levels of illiteracy and partly due to large distances and poor infrastructure outside the cities.

Since TV shows and movies are often syndicated internationally, product placement will almost always be internationaleven when this is not the intention of the manufacturing firm. Co-ordinating the international effort will depend on having a suitable PR agency with branches in the countries in which the firm trades; in the absence of this, the co-ordinating role would have to be undertaken from head office, with consequent problems of cross-cultural misunderstanding.

In many developing countries (and indeed elsewhere), international companies are met with suspicion due to the colonial past of some of their home countries. Cultural imperialism is often suspected, and therefore the incoming firm already has difficulties establishing a good reputation. In one country is not necessarily going to translate into the same in another country, and even if the reputation remains good it may be for other attributes.

For example, when the Disney Corporation established Euro Disney (which later became Disneyland Paris), it made the error of assuming that European children would know what Disneyland is. Because the firm had an established reputation in the USA and 'everybody knows Disney', it assumed that this would be the case in Europe. In fact, European adults had grown up with Tin Tin, Topo Gigio and Doctor Who, rather than with Donald Duck and Mickey Mouse. Although Disney was hardly an unknown firm, the company found to its cost that it had to go through a lengthy period of educating Europeans about Disney before customers began to come to the theme park in any great numbers. In any case, the European perception of Disneyland was (and still largely is) that the park is for children only, whereas this is not the case in the USA.

Corporate image advertising is often an important part of the process. When the Australian telecommunications system was opened up to competition in the early 1990s, Optus ran a long series of TV adverts emphasising the company's commitment to Australia; this was necessary, because 50 per cent of the company was foreign owned and many Australians objected to the concept of their telephone network being taken over by foreigners. The company's advertising emphasised that it was employing Australians and that it was 50 per cent Australian owned and managed. Telecom Australia (now Telstra) countered with a series of adverts emphasising its own Australian roots. At the time, Australian industry was in recession and the issue of foreign ownership of Australian assets was very much at the forefront of people's minds.

\section{Conclusion}

In Essence, PR is more than just goodwill, reputation and perception management, it also about building relationships between organisations. Good communications between organisations and their various target audiences is a key factor in building relationships with customers and opinion leaders. In the 21 st century public relations will become the key business tool, especially as the number of channels of communication increases daily, and as the media fragment.

\section{References}

Arnott, M. (1987). Effective employee communication, in Hart, N. (ed) Effective Corporate Relations. London: McGraw-Hill.

Blythe, J. (1997). The Essence of Consumer Behaviour. Hemel Hempstead: Prentice-Hall.

D'Aprix, R., quoted in Arnott, M. (1987). Effective employee communication, in Hart. N:(ed) Effective Corporate Relations. London: McGraw-Hill.

Kanter, R.M. (1985). The Change Masters: Corporate Entrepreneurs at Work. London: Unwin.

Maitland, A.J. (1983). To see ourselves as others see us. The BOC Group Management Magazine.

Morita, A. (1987). Made in Japan. Harmondsworth: Penguin.

Newman, K. (1986). The Selling of British Telecom. New York: Holt, Rinehart and Winston.

Pearson, A. J. (1980). Setting Corporate Objectives as a Basis for Action. Johannesburg: National Development and Management Foundation of South Africa.

Singh, J. (1988). Consumer complaint intention and behaviour: definition and taxonomical issues. Journal of Marketing, January, 93-107. 
Table 1 . The hierarchy of organisational needs

\begin{tabular}{|l|l|l|}
\hline Organizational & Requirements & Typical PR activity \\
\hline Output & Money, machines, manpower, Materials & Staff programs to attract the right people \\
\hline Survival & $\begin{array}{l}\text { Cash flow, profits, share performance, } \\
\text { customers }\end{array}$ & Publicity aimed at customers; events \\
\cline { 2 - 3 } Morale & Employee job satisfaction. & Staff newsletters, morale-boosting activites, etc. \\
\hline Acceptability & $\begin{array}{l}\text { Approval by the external stakeholders } \\
\text { (shareholders, government, customers, } \\
\text { suppliers society in general) }\end{array}$ & $\begin{array}{l}\text { External PR, shareholder reports, lobbying of } \\
\text { government departments and MPs, events for } \\
\text { suppliers and customers, favorable press releases }\end{array}$ \\
\hline Leadership & $\begin{array}{l}\text { Having a respected position in the } \\
\text { company's chosen field; this could be } \\
\text { customer satisfaction, employee } \\
\text { involvement, industry leadership in } \\
\text { technology, or several of these }\end{array}$ & $\begin{array}{l}\text { Corporate image-building exercises, customer-care } \\
\text { technolities, publicity about new products and } \\
\text { in universities, sponsorship of the arts }\end{array}$ \\
\hline
\end{tabular}

Table 2. Corporate slogans

\begin{tabular}{|l|l|}
\hline Example & Explanation \\
\hline $\begin{array}{l}\text { We're number two, so we try } \\
\text { harder' (Avis) }\end{array}$ & $\begin{array}{l}\text { This communicates to staff that the company is among the biggest, but that their } \\
\text { efforts to 'try harder' are recognized and appreciated. It Also conveys a valuable } \\
\text { image to customers. }\end{array}$ \\
\hline $\begin{array}{l}\text { Everything we do is driven } \\
\text { by you (Ford) }\end{array}$ & $\begin{array}{l}\text { This emphasizes the customer orientation of the company, that Ford is not merely } \\
\text { aiming to make as much money as possible but is also looking out for customers' } \\
\text { interests. }\end{array}$ \\
\hline $\begin{array}{l}\text { Your natural resource (Great } \\
\text { Southern Energy of Australia) }\end{array}$ & $\begin{array}{l}\text { The company emphasises is rural New South Wales roots and is honesty and } \\
\text { integrity. }\end{array}$ \\
\hline
\end{tabular}

Table 3. Criteria for successful press releases

\begin{tabular}{|l|l|}
\hline Criterion & Example \\
\hline $\begin{array}{l}\text { Stories must be newsworthy, } \\
\text { i.e. of interest to the reader }\end{array}$ & $\begin{array}{l}\text { Articles about your new lower prices are not newsworthy; articles about } \\
\text { opening a new factory creating 200 jobs are }\end{array}$ \\
\hline $\begin{array}{l}\text { Stories must not be merely } \\
\text { thinly disguised advertisements }\end{array}$ & $\begin{array}{l}\text { A story saying your new car is the best on the market at only £7999 will not be } \\
\text { published; a story saying your new car won the East African Safari Rally } \\
\text { probably would }\end{array}$ \\
\hline $\begin{array}{l}\text { Stories must fit the editorial style } \\
\text { of the magazine or paper to which } \\
\text { they are being sent }\end{array}$ & $\begin{array}{l}\text { An article sent to the Financial Times about your sponsored Fishing } \\
\text { competition will not be printed; an article about your company's takeover of a } \\
\text { competitor may be published }\end{array}$ \\
\hline
\end{tabular}


Table 4. Tasks for improving staff perception of the organisation

\begin{tabular}{|c|c|}
\hline Task & Rational and methods for achievement \\
\hline $\begin{array}{l}\text { Encourage an atmosphere } \\
\text { of pride }\end{array}$ & $\begin{array}{l}\text { Highlight the achievements of individuals, publicising these to others; } \\
\text { use innovative staff as agents of change }\end{array}$ \\
\hline $\begin{array}{l}\text { Provide suitable vehicles } \\
\text { for innovation }\end{array}$ & $\begin{array}{l}\text { Have communication channels that allow innovative ideas to be } \\
\text { disseminated and acted on across organizational boundaries }\end{array}$ \\
\hline Improve lateral communication & $\begin{array}{l}\text { This will improve the flow of innovative ideas; it can be done by encouraging joint } \\
\text { project teams, by encouraging interdepartmental social events and by exchanging } \\
\text { people } \\
\text { between departments where possible }\end{array}$ \\
\hline Cutting down layers of & By devolving decision making down the hierarchy and by cutting out layers of \\
\hline hierarchy & management, employees can feel more in control of what is happening within the firm \\
\hline $\begin{array}{l}\text { Increasing the available } \\
\text { information regarding } \\
\text { company plans and projects }\end{array}$ & $\begin{array}{l}\text { Reducing secrecy will ensure closer involvement of the those who have to implement } \\
\text { the plans, and may also lead to a reduction in mistakes caused through unrealistic } \\
\text { planning; the ground-floor staff are usually much closer to the problem than are senior } \\
\text { management }\end{array}$ \\
\hline $\begin{array}{l}\text { Ensure that the leadership is } \\
\text { aware of is limited perspective }\end{array}$ & $\begin{array}{l}\text { Running the organisation from the top is unlikely to be as effective as giving } \\
\text { employees more control over events, provided of course that the employees are attuned } \\
\text { to the organization's objectives. }\end{array}$ \\
\hline
\end{tabular}

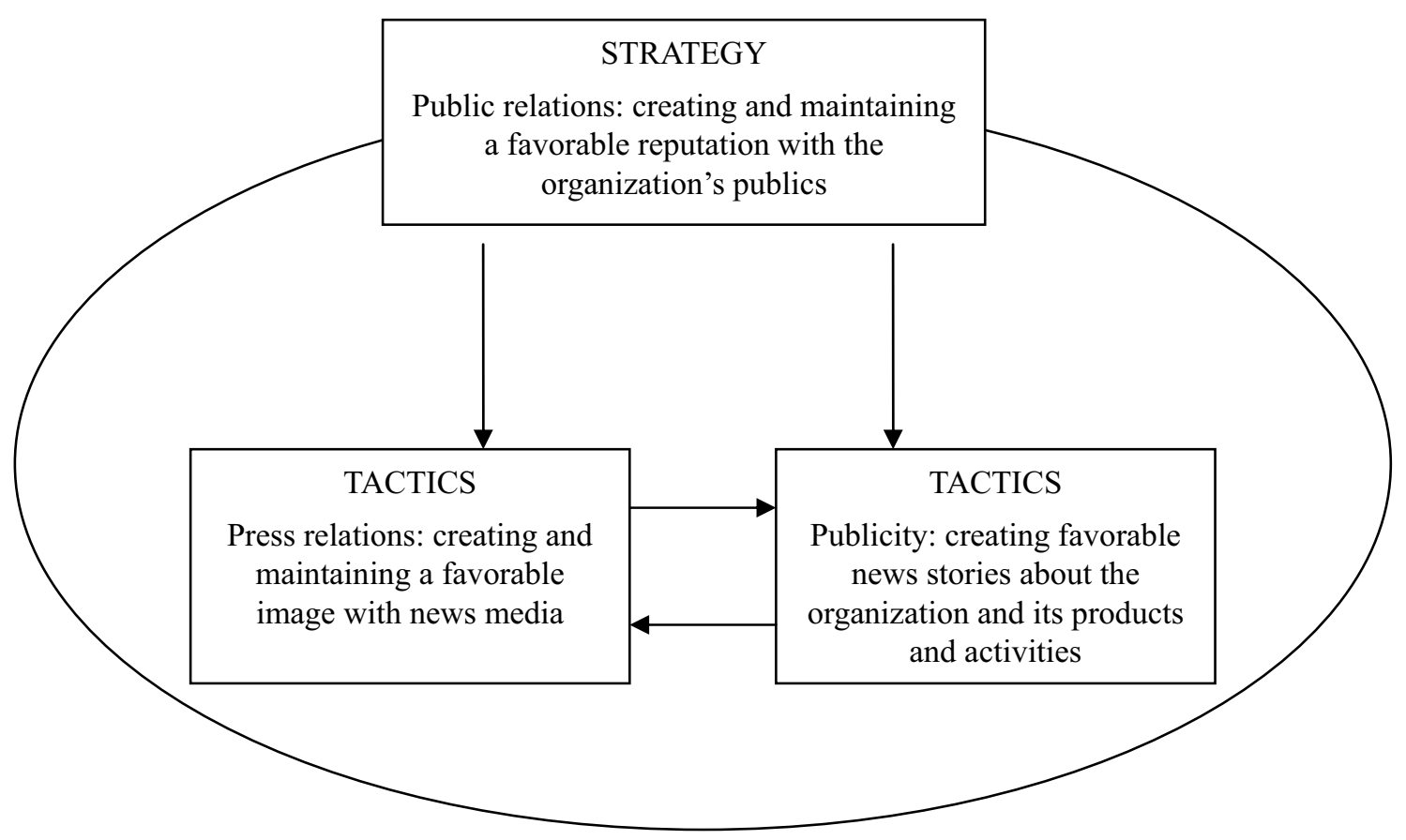

Figure 1. Publicity, PR and Public Relations 